\title{
Should liberal government regulate male circumcision performed in the name of Jewish tradition?
}

\author{
Raphael Cohen-Almagor ${ }^{1}$ (D)
}

Received: 24 June 2020 / Accepted: 6 October 2020 / Published online: 9 November 2020

(C) The Author(s) 2020

\begin{abstract}
The word "circumcision" comes from Latin circum (meaning "around") and cædere (meaning "to cut"). Cultural and religious justifications are employed to convince members of the community as well as outsiders that circumcision is reasonable and just. The purpose of the discussion is to suggest some cardinal changes to the practice of male circumcision in order to make it more humane and less painful to its subjects. Balancing between group rights and the rights of the child, it is essential to avoid unnecessary suffering. It is one of the liberal state's obligations to protect the best interests of vulnerable third parties. The article opens with some preliminary data about male circumcision and then explains its importance in Judaism. It examines the medical reasons for male circumcision and the risks involved in the practice; subsequently, it discusses the critique of male circumcision. The article also highlights the points of agreement and disagreement between those supporting and opposing the ritual and insists that male circumcision should be performed by using anaesthesia. The final part of the article includes a proposal for humane male circumcision that considers religious sentiments and the rights of the child, aiming to strike a reasonable balance between competing interests. I hope the proposal will be debated in parliaments in the western world.
\end{abstract}

Keywords Anaesthesia - Children's rights · Culture · Male circumcision · Judaism · Religion

If we are to achieve a richer culture, rich in contrasting values, we must recognize the whole gamut of human potentialities, and so weave a less arbitrary social fabric, one in which each diverse gift will find a fitting place. $\sim$ Margaret Mead

Raphael Cohen-Almagor

R.Cohen-Almagor@hull.ac.uk

1 Department of Politics, The University of Hull, Hull HU6 7RX, UK 
When Judith and Joel Cohen's son, Mishmar, was born, they did not consider the option of not circumcising him. This option was not on their cards. As Jews, circumcision is an integral and important part of their tradition. Circumcision signifies the lasting bond between God and the Jewish people. For many Jews, notwithstanding whether or not they believe in God, if they acknowledge the importance of tradition and believe in one's association with the Jewish people, circumcision is to be done.

While Judith and Joel did not question its necessity, they did debate how the circumcision should be performed: By a mohel (circumciser, a traditional person whose profession is to perform circumcision) or by a physician; with or without injections to relieve pain; in hospital or outside of hospital. At the ceremony itself, both Judith and Joel identified with Mishmar's pain. Judith could not stand it and went out of the room. Joel stayed behind; one of them needed to be there for Mishmar. After the cutting, the mohel gave Mishmar some wine drops to mitigate the pain. It took some time and effort to stop Mishmar's crying. Later Judith and Joel asked themselves whether circumcision was necessary as they felt uncomfortable with the painful imposition on their son. Ten years later, when their second son was born, they went through a similar process of decision-making, with the same result. Mishmar's brother was also subjected to circumcision, and Judith and Joel were in pain watching and hearing his suffering. Tradition is powerful.

Male circumcision is a common practice in Islamic and Jewish communities, and it is also practised by many Christian communities and tribes all over the world. It is estimated that $37-39 \%$ of the men in the world are circumcised. In Afghanistan, Comoros, Gabon, the Gaza Strip, Iran, Mauritania, Morocco, Tajikistan, Tunisia, the West Bank, Western Sahara and Yemen, the circumcision rate is estimated to be 99\% and above (Morris et al. 2016). In the Western world, male circumcision is far less popular. The striking exceptions are Israel and the United States. In Israel, the overwhelming majority of Jewish babies are circumcised. According to Rabbi Professor Avraham Steinberg, a medical ethicist, paediatric neurologist and an authority in this field, $97 \%$ of Jewish male babies are circumcised. ${ }^{1}$ In the United States, while the male circumcision rates had dropped the majority of babies still undergo circumcision. In $1979,64.5 \%$ of male babies were circumcised, while in $2010,58.3 \%$ underwent the practice (Vadnal 2018).

Male circumcision is a controversial practice. Recently, a bill was submitted in the Danish Parliament to outlaw the circumcision of minors for non-medical reasons (Times of Israel and JTA 2020). Analogies are made between this practice and the practice of Female Genital Mutilation (FGM), arguing that both amount to torture (Johnson 2010). The article explains the significance of male circumcision in Judaism and explores the validity and weight of the critique. Its methodology is based on a wide literature review of scholarship that has been published on male circumcision in various fields of study, including ethics, medicine, religion and culture. This extensive review was supplemented by discussions with religious and medical authorities. The article has also benefited from exchanges with scholars in the fields

1 Rabbi Professor Avraham Steinberg's personal communication (29 November 2019). 
of ethics and multiculturalism. Its major novelty lies in the proposal for humane male circumcision that I hope will be debated in parliaments in the western world.

The article opens with some preliminary data about male circumcision and then explains its importance in Judaism. It examines the medical reasons for male circumcision and the risks involved in the practice; subsequently, the article discusses the critique of male circumcision, and the main differences between this practice and FGM. The World Health Organisation (WHO) defines Female Genital Mutilation as "all procedures that involve partial or total removal of the external female genitalia or other injury to the female genital organs for non-medical reasons" (World Health Organization 2010a, b, 2018). The article also highlights the points of agreement and disagreement between those supporting and opposing the ritual and insists that the practice of male circumcision should be conducted in a way that is attentive to the rights of the child, perceiving this consideration as no less important than cultural and religious sentiments. The article concludes with a proposal for humane male circumcision that considers religious sentiments and the rights of the child, aiming to strike a reasonable balance between competing interests.

\section{Male circumcision}

The word "circumcision" comes from the Latin words circum (meaning "around") and cædere ("to cut"). Debates over male circumcision involve important yet conflicting considerations. It is argued that the practice violates the rights of children, including their right to health and bodily integrity (Hellsten 2004; Dekkers, Hoffer, and Wils 2005; Mazor 2013; Svoboda 2013a, b; Ungar-Sargon 2015) and their right to open future (Darby 2013; Sarajlic 2014). Children have rights in trust-rights that they cannot yet exercise, but which they will exercise upon reaching maturity. Thus, Darby (2013) argues that children rights require that the decision whether to circumcise be deferred until adulthood. Parents should not foreclose on or pre-empt their children's future options. Earp makes a similar argument, adding that if people grow up to dissociate from their parents' culture or religion, or to reject those norms or values, they might feel harmed or even mutilated by the circumcision. Therefore, circumcision is warranted only when it is medically necessary, or near that threshold (Earp 2016, 2019, pp. 229-230). Parents should enable their children the greatest possible scope for exercising personal life choices in adulthood (Darby 2013, p. 463; Feinberg 1992, pp. 76-97). Rights of the child need to be weighed against parental rights over their children, and against group rights to maintain tradition and practice this controversial ritual.

Circumcision is a cultural rite that is of importance to the group but not necessarily to society at large. The ritual is reasonable to the group in question but unreasonable, possibly offensive, in the eyes of outsiders. When such a debate arises, the scope of tolerance afforded to the group is questioned. Circumcision is a controversial ritual because it exerts pain in a psychosexually significant and sensitive (both physical and symbolic) part of the body that is usually construed in Western societies as "private" and "intimate". The subjects are young children who did not freely consent to this act (Goodman 1999). The act might undermine the children's 
well-being. All forms of ritual circumcision wish to put a physical mark of tradition and belonging to a community while excising a price from the children involved. Parents believe that the ritual is done for their children's good notwithstanding the pain, risk and suffering involved. Cultural and religious justifications are employed to convince members of the community as well as outsiders that circumcision is reasonable and just.

In the United States, the popularity of circumcision dates back 140 years to Dr Lewis Sayre, one of the founders of the American Medical Association. Sayre believed that many medical conditions had their root in a dysfunction in the genital area, and that circumcision could be used to treat a wide array of problems, from depression to mental health issues, syphilis and epilepsy. Circumcision was also promoted as a way of discouraging masturbation, and was regarded as clean and hygienic. It was particularly popular among the higher classes. Sayre's theories were later discredited, but not before they were accepted in other English-speaking countries, in particular in the UK, Canada, Australia and New Zealand (Denniston et al. 1999; Gollaher 2000; Hebblethwaite 2012; Svoboda 2013a, b). In the United States today, non-religious circumcision is usually performed in hospital when the infant is a few days old. While in the USA, Egypt, Saudi Arabia, the Gulf States and the Republic of Korea circumcision is provided almost exclusively by medically trained professionals, in North Africa, Pakistan, Indonesia, Israel and rural Turkey, the majority of providers are not medically trained (WHO April 2010a, b, p. 5).

Male circumcision consists of the removal of the prepuce, or foreskin, the tissue covering the head (glans) of the penis. The foreskin is freed from the head of the penis, and part of the foreskin is excised (Hutson 2004; Taylor et al. 1996). The foreskin contains nerve endings that are important for the enjoyment of sexual pleasure. Its glands produce lubricants that protect both the head of the penis and the female vagina (Men's Health Forum n/d). The circumcision generally heals in a week time. Circumcision of infants and pre-pubertal boys is simpler than circumcision of older boys and adults, because then the penis is relatively underdeveloped and the foreskin less vascular, and because suturing is usually not necessary. Healing tends to be quick and chances of complication are low (WHO 2009, chap. 6; WHO April 2010a, b, p. 46; Task Force on Circumcision 2012). ${ }^{2}$

In Judaism, the rite of male circumcision is significant. It is an integral part of the social and family life, perceived as contributing to communal heritage and the way communities define themselves.

\section{Male circumcision in judaism}

To Jews, male circumcision represents the covenant between Abraham and God. 98\% of male Jews are circumcised (Achituv 2012; Boorstein 2013). The Bible instructs that every Jewish boy needs to be circumcised. In the Book of Genesis,

\footnotetext{
${ }^{2}$ Earp argues the procedure is simpler for the operator; it's not necessarily better for the individual undergoing the procedure. See Myers and Earp (2019).
} 
chapter 17, it is told that when Abram was 99 years old, God appeared before him and said to him: "I will make a covenant between us and I will give you many, many descendants". Abram fell on his face, and God continued:

My covenant is with you; you will be the ancestor of many nations. And because I have made you the ancestor of many nations, your name will no longer be Abram but Abraham. I will make you very fertile. I will produce nations from you, and kings will come from you. I will set up my covenant with you and your descendants after you in every generation as an enduring covenant. I will be your God and your descendants' God after you. I will give you and your descendants the land in which you are immigrants, the whole land of Canaan, as an enduring possession. And I will be their God (Genesis 17).

This is a very important paragraph for the Jewish people that explicitly outlines the eternal connection between God and the Jewish people. To mark this milestone, and also to ensure that each and every generation is aware of this Covenant, God instructed Abraham to circumcise every male:

You must circumcise the flesh of your foreskins, and it will be a symbol of the covenant between us. On the eighth day after birth, every male in every generation must be circumcised, including those who are not your own children: those born in your household and those purchased with silver from foreigners. Be sure you circumcise those born in your household and those purchased with your silver. Your flesh will embody my covenant as an enduring covenant. Any uncircumcised male whose flesh of his foreskin remains uncircumcised will be cut off from his people. He has broken my covenant (Genesis 17).

The language is clear and it is phrased as a command that is not open to dispute or interpretation. Jews must do this or they will be cut off the Jewish people. Thus, the importance of circumcision for the Jewish people cannot be underestimated. There are many Jewish people who are not necessarily religious but still identify themselves as culturally Jewish. Their tradition, their culture, their way of life is to some extent Jewish. They identify with Judaism more than they do with any other religion; even if they are secular, they still define themselves as secular Jews. ${ }^{3}$ Most Jews in the world observe this symbolic ritual because they wish to maintain their association with the Jewish community.

One of the major Jewish sages, Moses ben Maimon, commonly known as Maimonides, also referred to by the acronym Rambam, was a 12th Century Sephardic Jewish philosopher, astronomer and physician. In his book, The Guide for the Perplexed, Maimonides (1186, Chap. XLIX) explained the logic behind male circumcision by saying that there are primarily two reasons for circumcision. First, its object is to limit sexual intercourse, and thus cause man to be moderate. This commandment has not been enjoined as a complement to a deficient physical creation, but

\footnotetext{
3 Mazor (2013) argues that boys who grow up in a community that endorses the ritual would most likely choose to become circumcised as an adult.
} 
"as a means for perfecting man's moral shortcomings". The bodily injury caused by circumcision does not interrupt any vital function, nor does it destroy the power of generation but it does counteract excessive lust; for "there is no doubt that circumcision weakens the power of sexual excitement, and sometimes lessens the natural enjoyment; the organ necessarily becomes weak when it loses blood and is deprived of its covering from the beginning" (Maimonides 1186, Chap. XLIX). Jewish Sages remind that the first person to perform this commandment was Abraham who was well known for fearing sin.

Second, this commandment gives to male Jews a common bodily sign, so that it is impossible for a non-Jew to say that he belongs to the Jewish people for some ulterior motive, and also it gives Jews a common sign of unity, connecting all Jews with the belief in God's Unity. Maimonides considers this purpose to be "perhaps more important" than circumcision's effect on libido (Maimonides 1186, Chap. XLIX).

Maimonides (1186, p. 379) explains that this law can only be kept and perpetuated if circumcision is performed when the child is of a very young age because of three reasons. First, if the operation were postponed till the boy had grown up, he would perhaps not submit to it. Second, "the young child has not much pain, because the skin is tender, and the imagination weak". Adults, on the other hand, "are in dread and fear of things which they imagine as coming" (Maimonides 1186, p. 379). Third, when a child is very young, "the parents do not think much of him; because the image of the child, that leads the parents to love him, has not yet taken a firm root in their minds. That image becomes stronger by the continual sight; it grows with the development of the child" (Maimonides 1186, p. 379).

Recent research refuted the second assumption, suggesting that babies experience pain much like adults. An Oxford research found that 18 of the 20 brain regions active in adults experiencing pain were active in babies. Scans also showed that babies' brains had the same response to a weak 'poke' as adults did to a stimulus four times as strong. Not only do babies experience pain much like adults but that they also have a much lower pain threshold (Goksan et al. 2015, p. 4; University of Oxford 2015; Michigan Medicine 2020).

\section{The practice of circumcision for medical reasons}

The use of circumcision for medical or health reasons is in much debate. The American Academy of Pediatrics (AAP) asserted that the health benefits of newborn male circumcision outweigh the risks, but the benefits are not great enough to recommend universal circumcision. Circumcision makes it easier to keep the end of the penis clean. Consequently, there is some evidence that circumcision has health benefits, including a decreased risk of urinary tract infections (UTI), a reduced risk of some sexually transmitted diseases in men, protection against penile tumour, and a reduced risk of cervical cancer in female sex partners (Task Force on Circumcision 2012). ${ }^{4}$ The World Health Organization (WHO) $(2007, \mathrm{n} / \mathrm{d})$ holds that there

\footnotetext{
${ }^{4}$ For critique, see Earp and Shaw (2017, pp. 8-26).
} 
is compelling evidence that male circumcision reduces the risk of heterosexually acquired HIV infection in men by approximately 60\%. The British National Health Service (NHS) explains in its recent guidelines (2018) that medical reasons for men to undergo circumcision include tight foreskin (phimosis), where the foreskin is too tight to be pulled back over the head of the penis (glans) which can sometimes cause pain; recurrent balanitis, where the foreskin and head of the penis become inflamed and infected; paraphimosis, where the foreskin cannot be returned to its original position after being pulled back, causing the head of the penis to become swollen and painful; balanitis xerotica obliterans which causes phimosis and, in some cases, also affects the head of the penis, which can become scarred and inflamed, and cancer of the penis (British Association of Urological Surgeons 2017; Wolbarst 1932; Dunsmuir and Gordon 1999; Larke et al. 2011). ${ }^{5}$ The NHS (2018) instructs that, in most cases, circumcision will only be recommended when other, less invasive and less risky treatments have been tried and have not worked. ${ }^{6}$

Arik V. Marcell of Johns Hopkins University argued that substantial science shows that male circumcision is beneficial not only in early life but later in life when men become sexually active - with lower risk of acquiring HIV, syphilis, human papillomavirus, and genital herpes, lower risk of cervical cancer in sexual partners and lower risk of penile cancer over a lifetime. Marcell (2012) maintained that African studies found that being circumcised reduces by approximately $50 \%$ the risk of HIV transmission.

\section{Risks of male circumcision}

As in any surgical procedure, there are risks associated with circumcision. Circumcision involves considerable pain and it carries the risk of bleeding and infection, irritation of the glans, increased risk of meatitis (inflammation of the opening of the penis), and risk of injury to the penis. These are rare when circumcision is performed by experienced professionals, and they can be easily and rapidly resolved. According to Professor Avraham Steinberg, some 75,000 male circumcisions are practised in Israel each and every year. The average number of complications each year is 40, mostly involving bleeding that is easily treated without leaving any permanent damage. ${ }^{7}$ In the United Kingdom, some 30,000 ritual circumcisions are performed every year, and Wheeler and Malone (2013) argue that only a few children were subsequently admitted to hospitals for treatment resulting from complications. Another study by Fox et al. (2019) suggests that over 8-year period 1266 post-circumcision problems were reported by NHS authorities and that many of those complications were relatively minor. An American study showed that the incidence of male circumcision associated adverse events was slightly less than $0.5 \%$ (El Bcheraoui et al. 2014). While acknowledging that complication rates from routine circumcision are low, critics argue that the chances of these complications being mutilatory, infective,

\footnotetext{
${ }^{5}$ For a survey of medical benefits of male circumcision, see Benatar and Benatar (2003, pp. 38-41).

${ }^{6}$ For supportive views of male circumcision, see Tobian and Gray (2011, pp. 1479-1480), Klausner and Morris (2012, pp. 455-456).

7 Personal communication (14 June 2019).
} 
or haemorrhagic are high and potentially catastrophic. Critics further argue that death, gangrene, and total or partial amputation are known adverse outcomes (Fox and Thomson 2005; Earp et al. 2018; Elhaik 2019).

\section{Critique of the practice}

Those associated with the holistic view hold that every organ of the body has a function, the foreskin included, and that we should not interfere with nature or God's creation. They maintain that the 'cleanliness of the penis' argument might have been true in certain eras but it is not nowadays, when we have baths and running water that provide us simple procedures to keep ourselves clean and tidy. Brian Earp argues that uncircumcised males have no difficulty to wash the glans; it takes about one second to retract the foreskin. ${ }^{8}$ Critics of male circumcision argue that the practice is painful and psychologically damaging (Boyle et al. 2002). Cutting the foreskin results in thickening and progressive desensitization of the head of the penis, particularly in older men (Goldman $\mathrm{n} / \mathrm{d}$ ). Without the protective, moisturizing prepuce, the glans decrease sensitivity. The foreskin is there for a reason. It is perfectly healthy, erogenous tissue that has important protective, sensory and sexual purposes. Like any other human tissue, it should only be removed for a good reason (Masem 2012, p. 455; Men's Health Forum n/d). Some have argued that the procedure is akin to clitoral prepuce (Benatar and Benatar 2003, p. 44; Earp 2015). While the remaining shaft skin can be restored with operation, the unique features of the double-layered foreskin, such as the highly innervated outer layer and highly sensitive inner layer, with its ridged band and suggested role in the ejaculatory reflex, are lost (Johnson 2013; Frisch et al. 2011). Critics mention the presence of scar tissue and associated discoloration and distinguish between early and late complications of the procedure. Early complications include cysts, irritation, urinary problems, buried penis, redundant foreskin, surgical site infection, penile skin bridge, possible altered sensitivity of the glans, glanular amputation, glanular necrosis, iatrogenic hypospadias, partial or complete amputation of the organ due to surgical error, haemorrhage and death. Late complications include inability to engage in sexual acts requiring foreskin motility, painful erections due to excessive skin removal, meatal stenosis, meatitis, phimosis, sepsis, and urethrocutaneous fistula (Munzer 2018; Fox et al. 2019; WHO 2009, chap. 1; WHO April 2010a, b, p. 46; WebMD 2020). It is further argued that the risk that an infection may become life-threatening is higher in infants due to their small size (Ungar-Sargon 2015).

The Royal Dutch Medical Association (KNMG) (2010) reported similar complications resulting from circumcision and also fibrosis of the skin, meningitis, herpes infections and necrotising complications which might lead to the complete amputation of the penis. Deaths have also been reported. In the United States, deaths following circumcision in clinical settings occur at a rate of approximately 1 for every 50,000 circumcisions (Earp et al. 2018; Shahvisi and Earp 2019). This figure is disputed. According to the American Academy of Family Physicians, death as a result

${ }^{8}$ Earp's comments on a draft of this chapter. Email 24 October 2019. 
of circumcision is rare, and mortality risk has been estimated to be $1 / 500,000$ procedures (American Academy of Family Physicians 2002). In Israel, Professor Avraham Steinberg argues that the number of deaths as a result of circumcision is zero. ${ }^{9}$ Critics further argue that the potential benefits of circumcision do not outweigh its harms when the procedure is not medically necessary, which is the case in the vast majority of infant circumcisions. Moreover, medical benefits of infant circumcision, such as a reduced rate of urinary infections, can be gained by resorting to far less traumatic and invasive ways than circumcision (Somerville 2000, chap. 8).

A systematic literature review analysed the evidence brought forward by critics of male circumcision. Claims that the procedure carries high risk were contradicted by low frequency of adverse events that were all minor and easily treated. Claims that male circumcision causes psychological harm were contradicted by studies finding no such harm. Arguments that the procedure impairs sexual function and pleasure were contradicted by high-quality studies finding no such adverse effect. Claims disputing the medical benefits of male circumcision were contradicted by a large body of high-quality evidence indicating protection against a wide range of infections, dermatological conditions, and genital cancers in males and the female sexual partners of men. Risk-benefit analyses reported that benefits exceed risks by 100-200 to 1 . To maximize benefits and minimize risks, the evidence supported early infant male circumcision rather than arguments that the procedure should be delayed until males are old enough to decide for themselves (Morris et al. 2019).

On 26 June 2012, for the first time in Germany, a court in Cologne ruled that circumcision of male minors for religious reasons causes "bodily harm" and violates "bodily integrity" notwithstanding the wishes of the parents. The court maintained that neither religious freedom nor rights of parents justify the practice. The court balanced the parents' right to religious freedom and the parental rights in education against the child's rights to bodily integrity and self-determination, concluding that the circumcision of a boy unable to voice consent is unlawful as it is contrary to the best interests of the child (Fateh-Moghadam 2012, p. 1134).

The ruling outraged both the Muslim and Jewish communities (Levey 2013). The German parliament reacted swiftly. On 12 December 2012, it passed a law allowing infant male circumcision for religious reasons when performed by a trained practitioner (Germann and Wackernagel 2015, pp. 443-444). Notwithstanding, in October 2013, the Council of Europe passed a resolution condemning the practice as a "violation of the physical integrity of children" and calling for a public debate in order to ban the practice "before a child is old enough to be consulted" (Laurance 2014). Norway, Sweden, Denmark, Finland and Iceland joined forces to call for a ban. While the incidence of male circumcision is relatively rare in all Scandinavian countries $(0.82 \%$ in Finland; $3.0 \%$ in Norway; $5.1 \%$ in Sweden; $0.1 \%$ in Iceland;

\footnotetext{
9 Avraham Steinberg's personal communication (14 June 2019). Steinberg doubts that the data about deaths in the USA is credible. He argues that cosmetic surgeries have far more complications than male circumcision, and he dismisses the critics of male circumcision as "baseless".
} 
5.3\% in Denmark) (Morris et al. 2016),${ }^{10}$ these countries find the practice as such problematic. However, no country has introduced a ban on male circumcision. ${ }^{11}$ In Iceland, a legislator took concrete steps to prohibit the practice for non-medical reasons. It was not specifically a bill to outlaw circumcision; rather, it was a proposal to change the wording of the law forbidding medically unnecessary female genital cutting from "girls" to "children". According to the proposal, a penalty of up to six years in prison should be imposed on anyone carrying out a circumcision for nonmedical reasons (Sherwood 2018). The proposal was dropped following widespread criticism, including from European Jewish leaders (Busby 2018). The ban was proposed by Silja Dögg Gunnarsdóttir of the Progressive Party who failed to understand the religious-cultural importance of the practice and consequently failed to consult Iceland's tiny Jewish and Muslim communities. She certainly did not anticipate the uproar that ensued (Cook 2018).

In Denmark, a citizens' petition calling for the introduction of a minimum age of 18 for circumcision to protect "children's fundamental rights" was put forth. The petition described circumcision as a form of abuse and corporal punishment, equating it with female genital mutilation (JTA 2018). However, this analogy between male circumcision and FGM is misplaced and wrong for a number of reasons and here I mention some of these reasons. Excessive forms of female circumcision, termed FGM, involve excising the visible part of the clitoris, the female organ that is most analogous to the male organ. Excising a girl's clitoris, part or all of the clitoris, is more like cutting off part or all of the boy's penis than removing his foreskin. The extent, scope and depth of the excision do matter. Severe bodily harm amounts to torture and is unjustifiable. Like torture, FGM involves the deliberate infliction of extreme pain and suffering. FGM does not only change the body. It is also a lifechanging operation. No wonder that women described it as if their whole life had stopped there and then (Abu Sahlieh 1994, p. 578).

Second, while male circumcision is regarded as a religious initiation rite in Islam and in Judaism, this is not true of FGM where the ritual is opened to interpretations. Some argue "there is clearly no basis whatsoever in any religion for the practice" of female circumcision (Mackay 1983, p. 36). Canonical Islamic texts offer relatively little justification for the practice (Gomaa 2013; Silverman 2004).

Third, the health consequences of FGM are entirely to the girl's disadvantage and there appears to be no medical reason for this operation. No medical expert disputes the argument that FGM inflicts major injury (World Health Organization 2020; Social Care, Local Government and Care Partnership 2016; Davar 1997; Lee 1994,

\footnotetext{
${ }_{10}$ The Danish National Board of Health estimates that 1000 to 2000 boys are ritually circumcised every year (Fagt 2018).

${ }^{11}$ In Australia, it's banned at public hospitals, but it's legal to have it done privately. In Germany, it can be performed by "specially qualified members of religious communities" for boys under 6 months, after which it must be performed by a doctor. Sweden requires a doctor or nurse to be present during circumcision, and mandates the use of anaesthesia. The most restrictive country is South Africa, which prohibits circumcision for boys under 16 except for religious or medical reasons, and requires consent for boys over 16. See Rose (2018).
} 
p. 35), ${ }^{12}$ while many medical experts argue that male circumcision cannot be considered an infringement upon the health or rights of boys and young men as it rarely implies permanent damage to health. In sub-Saharan Africa, male circumcision is used as a means of combating HIV transmission (Weiss et al. 2002; Johnson 2013, NHS 2018). ${ }^{13}$ Current epidemiological evidence clearly supports the promotion of male circumcision for HIV prevention, especially in populations with a high HIV prevalence and low circumcision rates (Oluwabunmi Olapade-Olaopa et al. 2019, p. 3).

Fourth, FGM is associated with sexual control. While some argue that male circumcision causes sexual diminution, the practice is not performed for reasons of gender repression. To the best of my knowledge, no one made the claim (often rehearsed when FGM is concerned) that male circumcision reflects deep-rooted preconceptions and prejudices about the lower status of men. Unlike FGM, claims are not made that male circumcision is an oppressive tradition designed to subjugate males.

Fifth, FGM not only keeps women "controlled"; it also diminishes their identity as sexual beings. Excessive forms of FGM rob sexuality and diminish women's ability to enjoy one of the most natural and pleasurable parts of life. On the other hand, male circumcision does not imply the end of a healthy sex life for a man. It is not about control and subjugation. Finally, men who underwent circumcision are not reluctant to have sexual intercourse as a result of the procedure. They do not suffer pain during intercourse.

The following table provides a summary of the rate of male circumcision in most of the world (Table 1).

\section{Points of agreement and disagreement between protagonists and critics of male circumcision}

Protagonists and critics of male circumcision agree on some things and disagree on many others (Benatar and Benatar 2003; British Medical Association 2004, pp. 259-263; Foddy 2013, p. 415; Earp 2013, pp. 418-420; Jacobs and Arora 2015, pp. 30-39; Earp and Darby 2015, pp. 23-30; Morris et al. 2017a, b, pp. 647-663; Mazor 2019 , pp. 1-16). They acknowledge that male circumcision is practised primarily for cultural and religious reasons, not for medical reasons. Protagonists and critics view circumcision for medical reasons as uncontroversial. So is consensual circumcision at an adult age. They also do not underestimate the importance of male circumcision for the relevant communities. Most ardent critics of male circumcision, who see some similarities between the practice and FGM, still acknowledge discerning significant differences. Only a small minority use the term "male genital mutilation"

\footnotetext{
12 For further discussion on female circumcision, see Brigman (1984-1985, pp. 337-357), Cohen-Almagor (1996); Stern (1997, pp. 89-111), Gillia (1997, pp. 579-614), Liu (1998, pp. 71-95), Kelson (1998, pp. 185-209), Messito (1997-1998, pp. 33-77), Mackie (1996, pp. 999-1017); Webber and Schonfeld (2003, pp. 65-66).

13 For critique, see Dowsett and Couch (2007, pp. 33-44).
} 
(Hellsten 2004, pp. 248-253; Johnson 2010, pp. 181-207). Even the most critical voices of male circumcision do not suggest putting a blanket ban on the practice as they understand that such a ban, very much like the 1920-1933 prohibition laws in the United States, ${ }^{14}$ would not be effective.

Protagonists and critics of male circumcision debate whether the practice is morally acceptable. They disagree on whether there are substantial similarities between male and female circumcision. Protagonists clearly demarcate the practices by calling the one male circumcision and the other FGM. A senior leader in the Jewish British community asked me to refrain from using the term "female circumcision" to avoid any association with male circumcision. Protagonists and critics disagree whether there is an absolute right to bodily integrity. Protagonists and critics disagree on issues pertaining to parental responsibilities and paternalism, whether parents should have the power to deform the integrity of the children's bodies, and how to assess children's best interests. They reach contrasting results when they balance the right of parents to determine their children's communal association vis-à-vis children rights. They assign different weights to harm as well as to medical risks and to non-medical benefits. The different weights to risks and benefits conform to their underlying views about the practices.

While there are medical justifications to male circumcision, these are usually brought by supporters of the practice who wish to reinforce their position. Protagonists and critics disagree about the significance of medical reasons for circumcision and about the injuries resulting from the practice. They disagree on whether the potential complications resulting from the procedure are significant (El Bcheraoui et al. 2014; Weiss et al. 2010). They disagree as to whether circumcision contributes to the cleanliness of the penis. They also disagree about the extent of reduction in sexual pleasure and the trauma that male circumcision might cause to its subjects. ${ }^{15}$ Furthermore, protagonists do not necessarily see reduction in sexual drive as a bad thing. They also disagree whether the issue of consent is important and as to what steps the state should take.

These are all, prima facie, reasonable disagreements. The issue presents a hard case for which there are a number of interpretations, and a number of possible solutions.

\section{A proposal}

Any form of circumcision is painful. Our reproduction organs are most sensitive and even slight scars can cause discomfort and agony. It is our responsibility to devise procedures that are as pain-free as possible in the safest possible environment. What form of state interference would seem reasonable?

\footnotetext{
14 Between 1920 and 1933, the United States imposed legal prohibition on the manufacture, sale, and transportation of alcoholic beverages.

15 Jacobs and Arora (2015, p. 32) presented evidence suggesting that there was no overall loss of sexual satisfaction in circumcised populations. See also Svoboda (2013a), Johnsdotter (2013, pp. 256-265), Van Howe (2013, pp. 214-229), Mendus (2013, pp. 230-233).
} 
Table 1 Percentage of circumcised males in each of the 237 countries and territories in the world (Morris et al. 2016)

\begin{tabular}{|c|c|c|c|c|c|}
\hline Country/territory & $\mathrm{MC}(\%)$ & Country/territory & $\mathrm{MC}(\%)$ & Country/territory & $\mathrm{MC}(\%)$ \\
\hline Afghanistan & 99.8 & Ghana & 91.6 & Oman & 87.7 \\
\hline Albania & 47.7 & Gibraltar & 6 & Pakistan & 96.4 \\
\hline Algeria & 97.9 & Greece & 4.7 & Palau & 95 \\
\hline American Samoa & 95 & Greenland & 0.1 & Panama & 0.95 \\
\hline Andorra & 1.1 & Grenada & 0.3 & Papua New Guinea & 10.1 \\
\hline Angola & 57.5 & Guam & 95 & Paraguay & 0.11 \\
\hline Anguilla & 0.3 & Guatemala & 0.11 & Peru & 3.7 \\
\hline Antigua \& Barbuda & 0.6 & Guernsey & 0.1 & Philippines & 91.7 \\
\hline Argentina & 2.9 & Guinea & 84.2 & Pitcairn Islands & 0 \\
\hline Armenia & 0.1 & Guinea-Bissau & 93.3 & Poland & 0.11 \\
\hline Aruba & 0.46 & Guyana & 12 & Portugal & 0.61 \\
\hline Australia & 26.6 & Haiti & 6.2 & Puerto Rico & 0.14 \\
\hline Austria & 5.8 & Holy See (Vatican) & 0.1 & Qatar & 77.5 \\
\hline Azerbaijan & 98.5 & Honduras & 0.1 & Romania & 0.34 \\
\hline Bahamas, The & 0.2 & Hong Kong & 28 & Russia & 11.8 \\
\hline Bahrain & 81.2 & Hungary & 0.78 & Rwanda & 13.3 \\
\hline Bangladesh & 93.2 & Iceland & 0.1 & Saint Barthelemy & 0.1 \\
\hline Barbados & 0.9 & India & 13.5 & Saint Helena, Ascens & 0.1 \\
\hline Belarus & 0.32 & Indonesia & 92.5 & Saint Kitts \& Nevis & 0.3 \\
\hline Belgium & 22.6 & Iran & 99.7 & Saint Lucia & 0.1 \\
\hline Belize & 0.1 & Iraq & 98.9 & Saint Martin \& Tristan & 0.1 \\
\hline Benin & 92.9 & Ireland & 0.93 & Saint Pierre \& Miquel & 0.2 \\
\hline Bermuda & 0.8 & Isle of Man & 0.2 & Saint Vincent \& Grena & 1.7 \\
\hline Bhutan & 1.0 & Israel & 91.7 & Samoa & 95 \\
\hline Bolivia & 0.11 & Italy & 2.6 & San Marino & 0.1 \\
\hline Bosnia \& Herzegovina & 41.6 & Jamaica & 14 & Sao Tome \& Principe & 0.1 \\
\hline Botswana & 15.1 & Japan & 9 & Saudi Arabia & 97.1 \\
\hline Brazil & 1.3 & Jersey & 0.1 & Senegal & 93.5 \\
\hline British Virgin Islands & 1.2 & Jordan & 98.8 & Serbia & 3.71 \\
\hline Brunei & 51.9 & Kazakhstan & 56.4 & Seychelles & 1.1 \\
\hline Bulgaria & 13.4 & Kenya & 91.2 & Sierra Leone & 96.1 \\
\hline Burkin Faso & 88.3 & Kiribati & 0.1 & Singapore & 14.9 \\
\hline Burma & 3.5 & Korea, North & 0.1 & Sint Maarten & 0.06 \\
\hline Burundi & 61.7 & Korea, South & 77.0 & Slovakia & 0.15 \\
\hline Cabo Verde & 0.1 & Kosovo Islands & 91.7 & Slovenia & 8.5 \\
\hline Cambodia & 3.5 & Kuwait & 86.4 & Solomon Islands & 95 \\
\hline Cameroon & 94.0 & Kyrgyzstan & 91.9 & Somalia & 93.5 \\
\hline Canada & 31.9 & Laos & 0.1 & South Africa & 44.7 \\
\hline Cayman Islands & 0.2 & Latvia & 0.38 & South Sudan & 23.6 \\
\hline Central African Republic & 63.0 & Lebanon & 59.7 & Spain & 6.6 \\
\hline Chad & 73.5 & Lesotho & 52 & Sri Lanka & 8.5 \\
\hline
\end{tabular}


Table 1 (continued)

\begin{tabular}{|c|c|c|c|c|c|}
\hline Country/territory & $\mathrm{MC}(\%)$ & Country/territory & $\mathrm{MC}(\%)$ & Country/territory & $\mathrm{MC}(\%)$ \\
\hline Chile & 0.21 & Liberia & 97.7 & Sudan & 39.4 \\
\hline China & 14.0 & Libya & 96.6 & Suriname & 15.9 \\
\hline Christmas Island & 0.1 & Liechtenstein & 4.8 & Svalbard & 0.1 \\
\hline Cocos (Keeling) & 95 & Lithuania & 0.2 & Swaziland & 8.2 \\
\hline Columbia & 4.2 & Luxembourg & 2.4 & Sweden & 5.1 \\
\hline Comoros & 99.4 & Macau & 0.1 & Switzerland & 5.9 \\
\hline Congo, Democrat Repub & 97.2 & Macedonia & 33.9 & Syria & 92.8 \\
\hline Congo, Republic & 70 & Madagascar & 94.7 & Taiwan & 8.3 \\
\hline Cook Islands & 95 & Malawi & 21.6 & Tajikistan & 99 \\
\hline Costa Rica & 0.15 & Malaysia & 61.4 & Tanzania & 72 \\
\hline Cote d'Ivoire & 96.7 & Maldives & 98.4 & Thailand & 23.4 \\
\hline Croatia & 1.3 & Mali & 86 & Timor-Leste & 6.4 \\
\hline Cuba & 0.11 & Malta & 0.3 & Togo & 95.2 \\
\hline Curacao & 0.07 & Marshall Islands & 0.1 & Tokelau & 95 \\
\hline Cyprus & 22.7 & Mauritania & 99.2 & Tonga & 95 \\
\hline Czech Republic & 0.14 & Mauritius & 16.6 & Trinidad \& Tobago & 5.8 \\
\hline Denmark & 5.3 & Mexico & 15.4 & Tunisia & 99.8 \\
\hline Djibouti & 96.5 & Micronesia, Fed States & 0.1 & Turkey & 98.6 \\
\hline Dominica & 0.2 & Moldova & 0.5 & Turkmenistan & 93.4 \\
\hline Dominican Republic & 13.7 & Monaco & 0.5 & Turks \& Caicos Is & 0.1 \\
\hline Ecuador & 0.11 & Mongolia & 4.4 & Tuvalu & 95 \\
\hline Egypt & 94.7 & Montenegro & 18.5 & Uganda & 26.7 \\
\hline El Salvador & 0.11 & Montserrat & 0.1 & Ukraine & 2.3 \\
\hline Equatorial Guinea & 87 & Morocco & 99.9 & United Arab Emirates & 76 \\
\hline Eritrea & 97.2 & Mozambique & 47.4 & United Kingdom & 20.7 \\
\hline Estonia & 0.25 & Namibia & 25.5 & United States & 71.2 \\
\hline Ethiopia & 92.2 & Nauru & 95 & Uruguay & 0.62 \\
\hline Falkland Islands & 0.1 & Nepal & 4.2 & Uzbekistan & 96.5 \\
\hline Faroe Islands & 0.1 & Netherlands & 5.7 & Vanuatu & 95 \\
\hline Fiji & 55 & New Caledonia & 50 & Venezuela & 0.33 \\
\hline Finland & 0.82 & New Zealand & 33.0 & Vietnam & 0.2 \\
\hline France & 14 & Nicaragua & 0.1 & Virgin Islands & 0.55 \\
\hline French Polynesia & 78 & Niger & 95.5 & Wallis \& Futuna & 0.1 \\
\hline Gabon & 99.2 & Nigeria & 98.9 & West Bank & 99.9 \\
\hline Gambia, The & 94.5 & Niue & 95 & Western Sahara & 99.6 \\
\hline Gaza Strip & 99.9 & Norfolk Island & 0.1 & Yemen & 99.0 \\
\hline Georgia & 10.6 & Northern Mariana Is & 90 & Zambia & 12.8 \\
\hline Germany & 10.9 & Norway & 3.0 & Zimbabwe & 9.2 \\
\hline
\end{tabular}


We need to recognize that male circumcision is deeply rooted in tradition. Finding a compromise over ideological and identity issues is most challenging. The communities that adopted the practice see male circumcision as a significant component of their identity. These communities have legitimate, strong historical claims for autonomy. Some liberals may claim that male circumcision is not morally justified. But we do not have legitimate grounds to enforce our morality upon the group because significant bodily damage is rarely inflicted upon those who are circumcised, because no straightforward coercion is employed against parents who refuse to circumcise their boys, and because of the historical claims for cultural autonomy that the said groups possess. The case would be different if evidence showed that families were to feel that they were being coerced to follow a certain conception of the good and were not allowed to leave their community. That is, the case would be different if these families were subject to designated coercion. Designated coercion is aimed at a certain individual who rebels against the discriminatory norm. This type of coercion is not aimed at convincing the entire cultural group of an irrefutable truth; instead it is a focused pressure on certain targeted individuals who seem to go astray from their community (CohenAlmagor 2006).

Evidence suggests that children should be circumcised in the early days or weeks of life, when the circumcision is safest, and unlikely to leave any trauma on the young infant (El Bcheraoui et al. 2014). While the issue of consent is important, on this particular matter of male circumcision there are weighty countervailing considerations that compellingly convince to perform circumcision in infancy. The health benefits include better hygiene; protection against urinary tract infection; eliminating the risk of balanitis and phimosis in childhood and after puberty which impedes micturition and results in difficult and painful erections in adolescence and adulthood as well as reduced likelihood of penile inflammation, HIV, genital herpes and other sexually transmitted infections (STIs) (Cooper et al. 2010, pp. 318-319; Morris et al. 2017a, b). In the future female sexual partners of males, infant circumcision means they too will be at reduced risk of STIs and cervical cancer. Furthermore, the infant is less mobile and, therefore, it is easier to preform anaesthesia; the procedure is simpler; healing is quicker; the cosmetic outcome is superior; cost-effectiveness is high, as is acceptability of the procedure. Moreover, psychological consequences for circumcision performed later in childhood are avoided as well as absence from work or school (Morris et al. 2012, p. 20).

Thus, circumcision is commonly decided by parents. The British Medical Association (2004) is supportive of allowing parents to make choices for their children, and believes that "neither society nor doctors should interfere unjustifiably in the relationship between parents and their children". At the same time, parental judgment should consider the child's best interests. While the liberal state has an obligation to protect vulnerable third parties, I am not confident that less harm will be caused by prohibiting male circumcision than by permitting it. Given the importance of the practice, making it illegal would only drive it underground. Orthodox (and also not-so-Orthodox) Muslims and Jews will continue to practice male circumcision as it is an integral and essential part of their religion 
and tradition. Furthermore, driving the practice underground will increase the overall harms to children. The circumcisers might be unprofessional and are likely to be operating in poor conditions, detrimental to the child's health. And if penalties against parents will be imposed in the form of fines, losing parental custody or imprisonment, the welfare of the child will be negatively impinged.

The state should have as little say as possible in personal matters. At least some of the critiques of male circumcision raise doubts. I do not think that circumcision is psychologically damaging and oppressive tradition designed to subjugate the individual and his sexuality (Boyleet al. 2002). While physical pain is inflicted on male babies, it is unlikely that they will remember the circumcision in the long run. Granted that babies should receive adequate pain-relief medication during the procedure and for the days ahead. As it takes approximately a week for the wound to heal, parents should be advised to ensure minimal contact with the wound as this may cause pain, including when it comes into contact with the baby's urine. Parents should be alert to alleviate the pain as much as they possibly can by attending to the baby's needs swiftly. As for psychological pain, the event is arguably more traumatic to the parents and other family members than to the infants. ${ }^{16}$ Yet, as the example of Judith and Joel Cohen that opened this paper shows, not all adults need to be present during the circumcision.

Parents should be free to opt out and decide not to circumcise their children. In non-orthodox Jewish communities, some parents opt out without been subject to penalties. Parents should also be free to decide that circumcision will be performed by special physicians in a medical setting and with various forms of anaesthesia. Weighing the pros and cons of intervention, it is argued that barring the practice will do very little good, outweighed by the harm caused by state interference.

Male circumcision should be performed with local anaesthesia. Subjects of the rituals should not suffer needlessly when analgesics are available. In this context, the KNMG's position paper (2010, p. 4) emphasized that circumcision is a surgical procedure and, therefore, it should be performed only by qualified healthcare professionals who follow all applicable scientific guidelines. This entails, inter alia, that "circumcisions can only be carried out under local or general anaesthetic, after thorough and precise advice and information has been given to the child's parents". The KNMG (2010) emphasized that this practice is not medically necessary and carries a risk of complications. This means that "extra-stringent requirements must be established with regard to this type of information and advice".

The KNMG recommended (1) local anaesthesia (2) performed by a qualified healthcare professional. As for the first recommendation, it has been argued that circumcision of neonates and children without suitable anaesthesia is unacceptable and is of great moral concern (Benatar and Benatar 2003, p. 43; Paix and Peterson 2012; Svoboda 2013a, b). Local or regional anaesthesia for neonatal circumcision requires a certain skill in anaesthesia to monitor the infant and intervene if the anaesthesia is inadequate. Anaesthesia with lignocaine-prilocaine cream is insufficient

\footnotetext{
16 Some speculate that circumcision may lead to persistent traumatic consequences for the infants. See Merkel and Putzke (2013, pp. 444-449), Boyle (2015, pp. 22-38). See also Taddio et al. (1997, pp. 599-603).
} 
while injected anaesthesia is painful due to the injection but it is comprehensive (Paix and Peterson 2012). WHO (2009; April 2010a, b, p. 11) recommends local anaesthesia with dorsal penile nerve block (DPNB). WHO holds that circumcision with EMLA (eutectic mixture of local anaesthetics) 5\% cream is safe and provides effective anaesthesia when applied correctly but not as effective as DPNB. ${ }^{17}$ Other studies suggest that newborns circumcised with the dorsal block and subcutaneous ring block in combination with the concentrated oral sucrose had the lowest pain scores. This combination is said to be the most effective anaesthetic and, therefore, the preferred option (Razmus et al. 2004; Sharara-Chami et al. 2017; Lander et al. 1997). However, this view is contested.

In his comments on a draft of this paper, Avraham Steinberg writes that the state should not intervene in a religious process as long as there is no damage to the babies. In his view, the main reason that the issue has arisen in recent years is the execution of a circumcision in hospitals by young and inexperienced interns. Consequently, there were complaints about continuous pain and suffering. In contrast, halachic circumcision performed by skilled circumcisers (mohalim) takes a very short time, and the degree of pain does not require anaesthesia by injection. The injections are painful in themselves. Steinberg thinks that if the state would insist on anaesthesia by injection, the result would be pirated circumcisions as many parents would opt to still approach the traditional mohalim. Also, the circumcision costs will skyrocket. The State of Israel will not fund the practice for the entire population. Moreover, the cumulative experience in Israel shows that in comparison to circumcisions conducted by physicians in other countries, no differences were found in the number of complications ${ }^{18}$; thus, there is no real benefit to performing the circumcision only by physicians.

Professor Leonid Eidelman, Chair of Anaesthesia in Rabin Medical Center in Israel, former President of the World Medical Association and Past President of Israel Medical Association agrees that penal block is not preferable to non-invasive anaesthesia. Like Steinberg, Eidelman explains that the injection itself hurt. It requires skill and might be dangerous to the baby if not done properly. There were cases where the injection was too deep, in the wrong place and/or with excessive dose. In Eidelman's view, the best way to perform male circumcision is to apply the EMLA ointment a few hours prior the procedure, apply it again during the procedure while giving the baby sugar to suck which relaxes the baby and mitigates the pain. After the operation, the baby should be given some pain relief, love and attention. Eidelman testified that when he circumcised his grandson he called a physician to perform the operation, and while the physician was qualified to use invasive forms of anaesthesia, Eidelman asked him to resort to the above method. ${ }^{19}$

Concurrently, Dr Nisar Mir argues that there is not one method that is clearly preferable to another. Dr Mir, who is a retired consultant paediatrician/neonatologist,

\footnotetext{
17 See also Rosen (2010), p. 31.

18 Personal communication (14 June 2019). See also Steinberg (2001, 2007), Reichman and Rosner (2000).

19 Professor Leonid Eidelman, personal communication (16 August 2020).
} 
Assistant Coroner in Cheshire, the United Kingdom, and formerly Professor and Head Department of Paediatrics King Saud University College of Medicine, said that there is no need for injection. Dr Mir explains that in the first month of life, the infants are at a higher risk of surgery and anaesthesia-related adverse events when compared with older children. Analgesia and anaesthesia for neonates require a good knowledge of neonatal and transitional physiology combined with skills in airway maintenance, vascular access and prompt management of unexpected adverse events or complications. A blood loss of about $25 \mathrm{ml}$ in a $3 \mathrm{~kg}$ baby is equivalent to a loss of nearly $10 \%$ of the infant's total blood volume and sepsis-related mortality is threefold higher in neonates on account of immature host defence mechanisms. ${ }^{20}$ Both Mir and Eidelman argue that inhalation anaesthesia is very effective. Decision Support in Medicine similarly holds that for infants and small children, mask induction with oxygen/nitrous oxide/sevoflurane is preferred (Decision Support in Medicine 2017).

As for the second KNMG recommendation that male circumcision should be performed by a qualified healthcare professional, this recommendation will face objections and criticisms. As mentioned above, in quite a few parts of the world, including Israel, the procedure is performed in the main by circumcisers who are not medically trained. According to Dr Mir, in the British National Health Services (NHS) there are not many physicians who perform circumcision. ${ }^{21}$ Insisting on regional anaesthesia by injection would exclude mohalim as they do not have the required knowledge and skill. In Dr Mir's opinion, the circumciser need not necessarily be a physician. Experience matters no less than credentials. A circumciser who performs the procedure a few times a day is more qualified than a physician who does it once a year. However, the circumciser needs to have a formal training and accreditation for performing the procedure and there needs to be system of audit and monitoring of the practice to ensure that all agreed safety standards are followed. ${ }^{22}$ According to Rabbi Professor Avraham Steinberg, Jewish Law (Halacha) proscribes full anaesthesia and permits local anaesthesia provided that it is not injected. ${ }^{23}$ Steinberg explains that Halacha objects to anaesthesia by injection because this procedure carries unnecessary risks, is painful no less than the circumcision, and prevents mohalim from conducting the ceremony as they have been doing for the past 3000 years. $^{24}$

In Israel, circumcision is not considered a surgical procedure, but a religious act. $^{25}$ Circumcisers are not under the responsibility of the Ministry of Health although they are performing surgical procedure. The vast majority of circumcisers are mohalim who learn their profession from former circumcisers, sometimes from

\footnotetext{
${ }^{20}$ Dr Nisar Mir, personal conversation (17 August 2020). See also Ratiuddin et al. (1994).

21 Dr Nisar Mir, personal conversation (17 August 2020).

22 Dr Nisar Mir, personal conversation (17 August 2020).

23 Personal communication (10 January 2019).

24 Personal communication (29 November 2019).

25 In his comments on a draft of this paper, Professor Leonid Eidelman qualified by saying that hundreds, maybe thousands of circumcisions were performed in adults and children of different age in Israel after 1990 as surgical procedures in operating rooms. Eidelman referred to the great immigration wave from Russia to Israel.
} 
their fathers. They need not learn medicine and they are regulated and monitored by a designated inter-ministerial committee, where the Ministry of Health has a representative, under the responsibility of the Chief Rabbinate which administers religious matters. Only a third of male circumcisions is performed by physicians under anaesthesia (Achituv 2012). ${ }^{26}$ Some of these physicians are also registered mohalim. Some are not. Steinberg advised that if the physician is not a registered mohel, the religious decree (mitzvah) of circumcision is not fulfilled. ${ }^{27}$

To address this delicate dilemma, a reasonable balancing act is required that would make the procedure safe and as pain-free as possible for the babies, and would not offend religious sentiments. The following proposal seeks to find a middle ground between tradition and protecting the rights of the child:

- Both parents should be involved and give consent for non-therapeutic circumcision. Parents are free to opt out and may decide not to circumcise their children.

- It is recommended to perform circumcision at a very young age. This is for the reasons stipulated by Maimonides (see supra) but also for medical reasons. Circumcision beyond infancy is riskier as the procedure is more complex, takes more time and the likelihood of complications is higher. A comprehensive study showed that the incidences of probable adverse events were approximately 20-fold and tenfold greater for males circumcised at age 1 to 9 years and at 10 years or older, respectively, compared with boys circumcised at an age younger than 1 year (El Bcheraoui et al. 2014). ${ }^{28}$ If circumcision is conducted at the adulthood stage of the boy's life, he should be involved in the decisionmaking process and have the ability to refuse undergoing the procedure if he so wishes.

- Male circumcision should be performed by someone who is fully qualified, who is familiar with the procedure and who can sort out potential complications.

- Male circumcision has been performed in Judaism for many generations. Traditional, Orthodox and Ultra-Orthodox Jews will find it difficult to accept the transfer of responsibility solely to physicians. Therefore, in the spirit of compromise, professional circumcisers, mohalim, could also practice the ritual. They should be fully trained and qualified to relieve human suffering. The State should administer and licence the procedure, ensuring that only people with the right qualifications could perform circumcision.

- Some physicians may refuse to perform non-therapeutic circumcisions for reasons of conscience. Conscientious objection is certainly a reasonable and valid ground for physicians to opt out (British Medical Association 2004).

\footnotetext{
${ }_{26}$ Professor Steinberg doubts that these data are correct. Personal communication (14 June 2019). Steinberg argues that only 40 of the 400 mohalim who were registered are physicians (personal communication, 29 November 2019). An updated list of mohalim is available at https://www.gov.il/he/departments/ general/mohalim_list (Hebrew).

27 Personal communication (10 January 2019).

28 For critical view, see Frisch and Earp (2018).
} 
- Before the procedure, the circumciser should ensure that the baby is healthy, of good size, has no medical concerns, and that there are no defects in the penal structure. The circumciser needs to ensure that the baby is fit for surgery (WHO 2009; Lenhart et al. 1997).

- Professional circumcisers should discuss the potential harms and benefits of circumcision with the parents or legal guardians.

- The procedure should be done in the appropriate hygienic setting, with appropriate clean, antiseptic instruments, preferably in a medical centre or near such a medical facility to which it would be possible to rush the baby in case of complications. Some babies have low threshold of pain. Their blood pressure might drop as a result. Bleeding and seizures are also among the possible complications. Therefore, it is useful to have nearby qualified medical professionals who know what to do in the minority of cases, where there are complications.

- The circumciser should enquire about known intolerance to anaesthesia or medication in the close family.

- The procedure should be conducted with local anaesthesia. If performed by a qualified physician, ring block (or inhalation anaesthesia) combined with oral sucrose and EMLA cream is required. If performed by a qualified circumciser, non-invasive local anaesthesia and oral sucrose are required.

- I have mentioned that according to some studies the combination of dorsal block, subcutaneous ring block and concentrated oral sucrose had the lowest pain scores and is therefore perceived to be the most effective anaesthetic for male circumcision. Some countries may consider training circumcisers to perform this procedure. According to this proposal, mohalim will not be required to study for a medical degree with specialization in anaesthesia. Instead, they will be required to participate in a designated course on anaesthesia for male circumcision. Such a course will be much shorter compared to studying for a medical degree. It will still require hundred hours of training, and that 20-30 procedures should be done under direct supervision. The training should encompass some neuroanatomy and physiology, anatomy and physiology of the male reproductive tract, pharmacology of anaesthetic agents and agents for treating complications. The medicine involved should include circumcision, local anaesthesia and their complications, as well as how to address these complications. Each country will specify the knowledge and skills that training should achieve in order to receive an official accreditation. Each national medical association will ensure that only people with the right qualifications will be able to perform male circumcision with this elaborate and skilful form of anaesthesia. The length of training might vary from nation to nation depending on the risk-averseness of government and other political considerations.

- After the procedure, adequate pain control such as Paracetamol in a proper dose is required. ${ }^{29}$

29 Professor Eidelman noted that it is easy to overdose. 
- Auditing is required. Circumcisers should report all cases of male circumcision that they perform. Mechanisms of quality control should be in place to monitor the number of explained complications.

- Parents, religious authorities, medical professionals, human rights activists and other stakeholders should engage in a constructive debate in the spirit of deliberative democracy about the pros and cons, benefits and risks of circumcision.

\section{Conclusion}

The purpose of the discussion was to suggest that male circumcision should be conducted in a humane fashion, making it as pain-free to its subjects as it is possible. Balancing between group rights and the rights of the child, it is essential to avoid unnecessary suffering. In this context, let me acknowledge, and reject the view that argues for intentional affliction of suffering on the child, wishing the baby to suffer. Some rabbinical authorities argue that circumcision requires some amount of pain while others contest this assertion. R. Meir Arik, known by his pseudonym Imrei Yosher, argued that pain is an integral part of the circumcision. Abraham endured pain to increase his reward and he set a precedent. Because Abraham suffered pain so we should not introduce any mitigating innovations to negate this aspect of circumcision (Reichman and Rosner 2000, p. 13). The majority of halachic authorities, however, disagree with Rabbi Arik and hold that pain is not a necessary requirement of circumcision (Reichman and Rosner 2000, p. 13). ${ }^{30}$ After all, Abraham was an adult and gave his consent. The issue remains contested and here religious belief comes into conflict with the rights of the child as well as the rights of the parents. Article 37 of the Convention on the Rights of the Child (1990) holds: "No child shall be subjected to torture or other cruel, inhuman or degrading treatment or punishment". Acknowledging the importance of non-therapeutic circumcision as a religious and cultural rite does not entail that we are required to concede to torture. It is one of the liberal state's obligations to protect the best interests of vulnerable third parties.

I hope my proposal will lead to an open debate with the communities, where the need for adequate analgesia is explained, and the rights of the child are safeguarded. An open discussion, conducted in civility and with mutual respect, would promote understanding of cultural needs while protecting the rights of all in aiming to secure a just and reasonable multicultural society.

Acknowledgements I am grateful to the following scholars for providing many constructive comments and criticisms: Geoffrey Brahm Levey, Bhikhu Parekh, Allan Jacobs, Brian Earp, Leonid Eidelman, Raanan Gillon, Elyakim Rubinstein, Avraham Steinberg, Steve Newman, Nisar Mir, Andrew Winter, Tony Smith, Bobby Silverman, Lester Grabbe and Gary Edles.

\footnotetext{
${ }^{30}$ See also Questions and Answers, https://www.eretzhemdah.org/newsletterArticle.asp?lang=he\&pagei $\mathrm{d}=48 \&$ cat $=1 \&$ newsletter $=295 \&$ article $=1083$ (Hebrew).
} 
Funding This paper was researched and written while the author was Distinguished Visiting Professor to the Faculty of Laws, University College London (UCL) (2019). The author is grateful to UCL for its support.

Data availability The datasets generated during and/or analysed during the current study are available from the corresponding author on reasonable request.

\section{Compliance with ethical standards}

Conflict of interest The author states that there is no conflict of interest.

Research involving human and animal rights Writing of this article did not involve research on humans or animals.

Open Access This article is licensed under a Creative Commons Attribution 4.0 International License, which permits use, sharing, adaptation, distribution and reproduction in any medium or format, as long as you give appropriate credit to the original author(s) and the source, provide a link to the Creative Commons licence, and indicate if changes were made. The images or other third party material in this article are included in the article's Creative Commons licence, unless indicated otherwise in a credit line to the material. If material is not included in the article's Creative Commons licence and your intended use is not permitted by statutory regulation or exceeds the permitted use, you will need to obtain permission directly from the copyright holder. To view a copy of this licence, visit http://creativecommons.org/licen ses/by/4.0/.

\section{References}

Abu Sahlieh SAA (1994) To mutilate in the name of Jehovah or Allah: legitimization of male and female circumcision. Med Law 13(4):575-622

Achituv N (2012) Blood circumcision, Haaretz (June 14) (Hebrew).

American Academy of Family Physicians (2002) Position paper on neonatal circumcision (Leawood, Kansas, February 14). https://www.cirp.org/library/statements/aafp2002/

Benatar M, Benatar D (2003) Between prophylaxis and child abuse: the ethics of neonatal male circumcision. Am J Bioethics 3(2):38-41

Boorstein M (2013) A small but growing number of Jews are questioning the ancient ritual of circumcision, The Washington Post (December 28). https://www.washingtonpost.com/local/a-small-butgrowing-number-of-jews-are-questioning-the-ancient-ritual-of-circumcision/2013/12/25/d24c5 a4e-6403-11e3-aa81-e1dab1360323_story.html

Boyle GJ (2015) Circumcision of Infants and children: short-term trauma and long-term psychosexual harm. Adv Sex Med 5(2):22-38

Boyle GJ, Goldman R, Svoboda JS, Fernandez E (2002) Male circumcision: pain, trauma and psychosexual sequelae. J Health Psychol 7(3):329-343

Brigman WE (1984-1985) Circumcision as child abuse: the legal and constitutional issues. J Fam Law 23(3):337-357

British Association of Urological Surgeons (2017) Circumcision. Information about your procedure, Leaflet No: 16/077 (June). https://www.baus.org.uk/_userfiles/pages/files/Patients/Leaflets/Circu mcision.pdf

British Medical Association (2004) The law and ethics of male circumcision: guidance for doctors. J Med Ethics 30(3):259-263

Busby M (2018) Danish parliament to consider becoming first country to ban circumcision of boys, The Independent (June 3). https://www.independent.co.uk/news/world/europe/denmark-boyhood-circu mcision-petition-danish-parliament-debate-a8381366.html 
Cohen-Almagor R (1996) Female circumcision and murder for family honour among minorities in Israel. In: Schulze K, Stokes M, Campbell C (eds) Nationalism, minorities and diasporas: identities and rights in the middle east. I.B. Tauris, London, pp 171-187

Cohen-Almagor R (2006) On compromise and coercion. Ratio Juris 19(4):434-455

Convention on the Rights of the Child (1990) https://www.ohchr.org/en/professionalinterest/pages/crc. aspx

Cook M (2018) Iceland dumps proposed ban on male circumcision, BioEdge (May 13). https://www. bioedge.org/bioethics/iceland-dumps-proposed-ban-on-male-circumcision/12690

Cooper DA, Wodak AD, Morris BJ (2010) The case for boosting infant male circumcision in the face of rising heterosexual transmission of HIV. Med J Aust 193:318-319

Darby RJL (2013) The child's right to an open future: is the principle applicable to non-therapeutic circumcision? J Med Ethics 39:463-468

Davar BA (1997) Women: female genital mutilation. Texas J Women Law 6:257-271

Decision Support in Medicine (2017) Anesthesiology: circumcision, Clinical Pain Advisor. https://www. clinicalpainadvisor.com/home/decision-support-in-medicine/anesthesiology/circumcision/

Dekkers W, Hoffer C, Wils J-P (2005) Bodily integrity and male and female circumcision. Med Health Care Philos 8(2):179-191

Denniston GC, Hodges FM, Fayre Milos M (eds) (1999) Male and female circumcision: medical, legal and ethical considerations in pediatric practice. Kluwer Academic/Plenum Publishers, New York

Dowsett GW, Couch M (2007) Male Circumcision and HIV prevention: is there really enough of the right kind of evidence? Reprod Health Matters 15(29):33-44

Dunsmuir WD, Gordon EM (1999) The history of circumcision. BJU Int 83(Suppl 1):1-12

Earp BD (2013) The ethics of infant male circumcision. J Med Ethics 39(7):418-420

Earp B (2015) Female Genital Mutilation and Male Circumcision: toward an autonomy-based ethical framework. Medicolegal and Bioethics 5:89-104

Earp BD (2016) In defence of genital autonomy for children. J Med Ethics 41(3):158-163

Earp BD (2019) The child's right to bodily integrity. In: Edmonds D (ed) Ethics and the contemporary world. Routledge, Abingdon and New York, pp 229-230

Earp BD, Darby R (2015) Does science support infant circumcision? Skeptic 25(3):23-30

Earp BD, Shaw DM (2017) Cultural bias in American medicine: the case of infant male circumcision. J Pediatric Ethics 1(1):8-26

Earp BD, Allareddy V, Allareddy V, Rotta AT (2018) Factors associated with early deaths following neonatal male circumcision in the United States, 2001-2010. Clin Pediatr 57(13):1532-1540

El Bcheraoui C, Zhang X, Cooper CS et al (2014) Rates of adverse events associated with male circumcision in US medical settings, 2001 to 2010. JAMA Pediatrics 168(7):625-634

Elhaik E (2019) Neonatal circumcision and prematurity are associated with sudden infant death syndrome (SITS). J Clin Transl Res 4(2):136

Fagt J (2018) Det siger Sundhedsstyrelsen og reglerne om omskæring af drenge, DR (January 10) (Danish). https://www.dr.dk/nyheder/indland/det-siger-sundhedsstyrelsen-og-reglerne-om-omskaering -af-drenge

Fateh-Moghadam B (2012) Criminalizing male circumcision? Case note: Landgericht Cologne, Judgment of 7 May 2012-No. 151, Ns 169/11, German Law J. 13, no. 9: 1134.

Feinberg J (1992) The child's right to an open future. In: Feinberg J (ed) Freedom and fulfilment: philosophical essays. Princeton, Princeton University Press, pp 76-97

Foddy B (2013) Medical, religious and social reasons for and against an ancient rite. J Med Ethics 39(7):415. https://doi.org/10.1136/medethics-2013-101605

Fox M, Thomson M (2005) A covenant with the status quo? Male circumcision and the new BMA guidance to doctors. J Med Ethics 31:463-469

Fox M, Thomson M, Warburton J (2019) Non-therapeutic male genital cutting and harm: law, policy and evidence from U.K. hospitals. Bioethics 33:471-472

Frisch M, Earp BD (2018) Circumcision of male infants and children as a public health measure in developed countries: a critical assessment of recent evidence. Global Public Health 13(5):626-641

Frisch M, Lindholm M, Grønbæk M (2011) Male circumcision and sexual function in men and women: a survey-based, cross-sectional study in Denmark. Int J Epidemiol 40(5):1367-1381

Genesis, 17

Germann M, Wackernagel C (2015) The circumcision debate from a German constitutional perspective. Oxford J Law Religion 4:443-444

Gillia BA (1997) Female genital mutilation: a form of persecution. New Mexico L Rev 27:579-614 
Goksan S, Hartley C, Emery F et al (2015) fMRI reveals neural activity overlapbetween adult and infant pain. eLife 4:e06356

Goldman R (n/d) How male circumcision harms women, Circumcision Resource Center. https://www. circumcision.org/harmswomen.htm

Gollaher D (2000) Circumcision: a history of the world's most controversial surgery. Basic Books, New York

Gomaa A (2013) The Islamic view on female circumcision. Afr J Urol 19(3):123-126

Goodman J (1999) Jewish circumcision: an alternative perspective. BJU Int 83(1):22-27

Hebblethwaite C (2012) Circumcision, the ultimate parenting dilemma, BBC (August 21). https://www. bbc.co.uk/news/magazine-19072761

Hellsten SK (2004) Rationalising circumcision: from tradition to fashion, from public health to individual freedom - critical notes on cultural persistence of the practice of genital mutilation. J Med Ethics 30:248-253

Hutson JM (2004) Circumcision: a surgeon's perspective. J Med Ethics 30:238-240

Jacobs AJ, Arora KS (2015) Ritual male infant circumcision and human rights. Am J Bioethics 15(2):30-39

Johnsdotter S (2013) Discourses on sexual pleasure after genital modifications: the fallacy of genital determinism (a response to J. Steven Svoboda). Global Discourse 3(2):256-265

Johnson M (2010) Male genital mutilation: beyond the tolerable? Ethnicities 10(2):181-207

Johnson MT (2013) Religious circumcision, invasive rites, neutrality and equality: bearing the burdens and consequences of belief. J Med Ethics 39(7):450-455

JTA (2018) Danish Parliament Committee Approves Draft Resolution to Ban Circumcision, Haaretz (September 30). https://www.haaretz.com/world-news/europe/danish-parliament-committee-appro ves-draft-resolution-to-ban-circumcision-1.6514879

Kelson GA (1998) Female circumcision in the modern age: should female circumcision now be considered grounds for Asylum in the United States? Buffalo Hum Rights L Rev 4:185-209

Klausner JD, Morris BJ (2012) Benefits of male circumcision. JAMA 307(5):455-456

Lander J, Brady-Fryer B, Metcalf JB et al (1997) Comparison of ring block, dorsal penile nerve block, and topical anesthesia for neonatal circumcision. J Am Med Assoc 278(24):2157-2162

Larke NL, Thomas SL, dos Santos SI et al (2011) Male circumcision and penile cancer: a systematic review and meta-analysis. Cancer Causes Control 22(8):1097-1110

Laurance J (2014) Circumcision: a necessary cut or bodily harm?, The Independent (May 6). https:// www.independent.co.uk/life-style/health-and-families/features/circumcision-a-necessary-cut-orbodily-harm-9328250.html

Lee K (1994) Female genital mutilation-medical aspects and the rights of children. Int J Children's Rights 2(1):35-44

Lenhart JG, Lenhart NM, Reid A, Chong BK (1997) Local anesthesia for circumcision: which technique is most effective? J Am Board Fam Pract 10(1):13-19

Levey GB (2013) Thinking about infant male circumcision after the cologne court decision. Global Discourse 3(2):326-331

Liu JA (1998) When law and culture clash: female genital mutilation, a traditional practice gaining recognition as a global concern. New York Int L Rev 11:71-95

Mackay RD (1983) Is female circumcision unlawful?, Criminal Law Rev 717-722

Mackie G (1996) Ending footbinding and infibulation: a convention account. Am Sociol Rev 61:999-1017

Maimonides M (1186) A guide for the perplexed. https://oll.libertyfund.org/titles/maimonides-a-guide -for-the-perplexed

Marcell AV (2012) Greater benefits of infant circumcision, Johns Hopkins Medicine (October 15). https ://www.hopkinsmedicine.org/news/articles/greater-benefits-of-infant-circumcision

Masem M (2012) Benefits of male circumcision. JAMA 307(5):455

Mazor J (2013) The child's interests and the case for the permissibility of male infant circumcision. J Med Ethics 39(7):421-428

Mazor J (2019) On the strength of children's right to bodily integrity: the case of circumcision. J Appl Philos 36(1):1-16

Mendus M (2013) Infant male circumcision in the public square: applying the public reason of John Rawls (a reply to Robert Van Howe). Global Discourse 3(2):230-233

Men's Health Forum (n/d) Circumcision FAQs. https://www.menshealthforum.org.uk/circumcision-faqs 
Merkel R, Putzke H (2013) After Cologne: male circumcision and the law Parental right, religious liberty or criminal assault? J Med Ethics 39(7):444-449

Messito CM (1997-1998) Regulating rites: legal responses to female genital mutilation in the west. In the Public Interest 16:33-77

Michigan Medicine (2020) Pain and your infant: medical procedures, circumcision and teething. https:// www.med.umich.edu/yourchild/topics/paininf.htm

Morris BJ, Waskett JH, Banerjee J et al (2012) A "snip" in time: what is the best age to circumcise? BMC Pediatr 12:20

Morris BJ, Wamai RG, Henebeng EB et al (2016) Estimation of country-specific and global prevalence of male circumcision. Popul Health Metrics 14(4):1-4. https://doi.org/10.1186/s12963-016-0073-5

Morris BJ, Kennedy SE, Wodak AD et al (2017a) Early infant male circumcision: systematic review, riskbenefit analysis, and progress in policy. World J Clin Pediatr 6(1):89-102

Morris BJ, Krieger JN, Klausner JD, Rivin BE (2017b) The ethical course is to recommend infant male circumcision-arguments disparaging american academy of pediatrics affirmative policy do not withstand scrutiny. J Law Med Ethics 45:647-663

Morris BJ, Moreton S, Krieger JN (2019) Critical evaluation of arguments opposing male circumcision: a systematic review. J Evid Based Med 1-28.

Munzer SR (2018) Examining nontherapeutic circumcision. Health Matrix 28:1-78

Myers A, Earp BD (2019) What is the best age to circumcise? A medical and ethical analysis. Bioethics. https://doi.org/10.1111/bioe.12714

NHS (2018) Circumcision in men, NHS (November 5). https://www.nhs.uk/conditions/circumcisi on-in-men/

Oluwabunmi Olapade-Olaopa E, Salami MA, Lawal TA (2019) Male circumcision and global HIV/AIDS epidemic challenges. Afr J Urol 25(1):3. https://doi.org/10.1186/s12301-019-0005-2

Paix BR, Peterson SE (2012) Circumcision of neonates and children without appropriate anaesthesia is unacceptable practice. Anaesth Intensive Care 40:511-516

Questions and Answers (n/d) https://www.eretzhemdah.org/newsletterArticle.asp?lang=he\&pagei $\mathrm{d}=48 \&$ cat $=1 \&$ newsletter $=295 \&$ article $=1083$ (Hebrew).

Ratiuddin S, El-Awad ME (1994) Mir NA (1994) Bacterial Meningitis: T cell activation and immunoregulatory CD4+ T cell subset alteration. Allergy Clin Immunol 93(4):793-798

Razmus IS, Dalton ME, Wilson D (2004) Pain management for newborn circumcision. Pediatric Nurs 30(5):414-417

Reichman E, Rosner F (2000) The use of anesthesia in circumcision: a re-evaluation of the halakhic sources. Tradition 34(3):6-26

Rose J (2018) 4 Countries with rules regulating male circumcision, now that it's becoming more controversial, Romper (March 7). https://www.romper.com/p/4-countries-with-rules-regulating-malecircumcision-now-that-its-becoming-more-controversial-8429116

Rosen M (2010) Anesthesia for ritual circumcision in neonates. Paediatrics Anaesth 20:1124-1127

Royal Dutch Medical Association (KNMG) (2010) Non-therapeutic Circumcision of Male Minors (Amsterdam, May). https://www.knmg.nl/circumcision/

Sarajlic E (2014) Can culture justify infant circumcision? Res Publica 20(4):327-343

Shahvisi A, Earp BD (2019) the law and ethics of female genital cutting. In: Creighton S, Liao L-M (eds) Female genital cosmetic surgery: solution to what problem? Cambridge University Press, Cambridge

Sharara-Chami R, Lakissian Z, Charafeddine L et al (2017) Combination analgesia for neonatal circumcision: a randomized controlled trial. Pediatrics 140(6):e20171935

Sherwood H (2018) Iceland law to outlaw male circumcision sparks row over religious freedom, The Observer (February 18). https://www.theguardian.com/society/2018/feb/18/iceland-ban-male-circu mcision-first-european-country

Silverman EK (2004) Anthropology and circumcision. Annu Rev Anthropol 33:419-445

Social Care, Local Government and Care Partnership (2016) Female Genital Mutilation Risk and Safeguarding; Guidance for professionals (London).

Somerville MA (2000) The ethical canary: science, society and the human spirit. Viking, Toronto

Steinberg A (2001) Anaesthesia in circumcision, medical and halachic perspectives, Shana Be'Shana (Hebrew).

Steinberg A (2007) Anesthesia in circumcision-Medical and halachic consideration. Jewish Med Ethics $6: 15-25$ 
Stern A (1997) Female genital mutilation: United States Asylum Laws are in need of reform. Am Univ J Gender Law 6(1997):89-111

Svoboda JS (2013a) Circumcision of male infants as a human rights violation. J Med Ethics 39(7):469-474

Svoboda JS (2013b) Promoting genital autonomy by exploring commonalities between male, female, intersex, and cosmetic female genital cutting. Global Discourse 3(2):237-255

Taddio A, Katz J, Ilersich AL, Koren G (1997) Effect of neonatal circumcision on pain response during subsequent routine vaccination. The Lancet 349:599-603

Task Force on Circumcision (2012) Male circumcision. Pediatrics 130(3):e756

Taylor JR, Lockwood AP, Taylor AJ (1996) The prepuce: specialized mucosa of the penis and its loss to circumcision. Br J Urol 77(2):291-295

Times of Israel and JTA (2020) Netanyahu thanks Danish prime minister for opposition to circumcision ban, Times of Israel (September 13). https://www.timesofisrael.com/netanyahu-thanks-danis h-prime-minister-for-opposition-to-circumcision-ban/?utm_source=The+Daily+Edition\&utm_ campaign=daily-edition-2020-09-13\&utm_medium=email\#gs.g1dg4i

Tobian AAR, Gray RH (2011) The medical benefits of male circumcision. JAMA 306(13):1479-1480

Ungar-Sargon E (2015) On the impermissibility of infant male circumcision: a response to mazor. J Med Ethics 41(2):186-190

University of Oxford (2015) Babies Feel Pain 'Like Adults': Most babies not given pain meds for surgery, Science Daily (April 21). https://www.sciencedaily.com/releases/2015/04/150421084812.htm

Vadnal J (2018) Why fewer guys are getting circumcised, Cosmopolitan (August 21). https://www.cosmo politan.com/sex-love/a22094429/why-fewer-guys-are-getting-circumcised/

Van Howe R (2013) Infant male circumcision in the public square: applying the public reason of John Rawls. Global Discourse 3(2):214-229

Webber S, Schonfeld T (2003) Cutting history, cutting culture: female circumcision in the United States. Am J Bioethics 3(2):65-66

WebMD (2020) Circumcision basics. https://www.webmd.com/sexual-conditions/guide/circumcision

Weiss HA, Quigley MA, Hayes RJ (2002) Male circumcision and risk of HIV infection in Sub-Saharan Africa: a systematic review and meta-analysis. AIDS 14:2361-2370

Weiss HA, Larke N, Halperin D et al (2010) Complications of circumcision in male neonates, infants and children: a systematic review. BMC Urology 10:2

Wheeler R, Pat Malone P (2013) Male Circumcision: risk versus benefit. Arch Dis Child 98:322

Wolbarst A (1932) Circumcision and penile cancer. The Lancet 1(5655):150-153

World Health Organization (WHO) (2007) Male circumcision-global trends and determinants of prevalence, safety and acceptability, World Health Organization and Joint United Nations Programme on HIV/AIDS

World Health Organization (WHO) (2009) Manual for male circumcision under local anaesthesia, version 3.1 (December).

World Health Organization (WHO) (2010a) Global strategy to stop health-care providers from performing female genital mutilation. WHO, Geneva

World Health Organization (WHO) (2010b) Neonatal and child male circumcision: a global review (April).

World Health Organization (WHO) (2018) Female genital mutilation (January 31). https://www.who.int/ en/news-room/fact-sheets/detail/female-genital-mutilation

World Health Organization (WHO) (2020) Female genital mutilation, WHO Fact sheet. https://www. who.int/news-room/fact-sheets/detail/female-genital-mutilation

World Health Organization (WHO) (n/d) Male circumcision for HIV prevention. https://www.who.int/ hiv/topics/malecircumcision/en/ 